frequent determination of the fasting blood-sugar and sugar tolerance tests with betacytotropic substances should be carried out. Proof of organic hyperinsulinism is a raised plasma-insulin level with lowered blood-sugar levels.

During the last few years 25 patients with organic hyperinsulinism were operated at the Surgical University Clinic, Munich. In three cases a carcinoma was involved.

15 patients whom we have been able to contact are doing well, 2 months to 9 years after the operation.

Zusammenfassung. Häufige Symptome eines organischen Hyperinsulinismus sind morgendliche Schwächezustände und Anfälle von Bewußtlosigkeit. Als diagnostische Maßnahmen dienen die häufige Bestimmung des Nüchternblutzuckers und die Belastungstests mit betacytotropen Substanzen. Beweisend für einen organischen Hyperinsulinismus ist der erhöhte Plasmainsulinspiegel bei erniedrigten Blutzuckerwerten.

Während der letzten Jahre wurden an der Münchner Chirurgischen Universitätsklinik 25 Patienten mit einem organischen Hyperinsulinismus operiert. Dabei handelte es sich dreimal um ein Carcinom.

15 Kranken, die wir erreichen konnten, geht es jetzt, 2 Monate bis 9 Jahre nach der Operation, gut.

\title{
143. Inselzelladenome: Diagnostik und operative Behandlung
}

\section{G. Koch-Hamburg}

\section{Islet Cell Adenoma: Diagnosis and Operative Treatment}

Summary. Prerequisite for successful operative procedures in organic hyperinsulinism is aimed diagnosis with provoked hyperglykaemia, plasma insulin estimation (IMI) and selective arteriography. The type of operation depends on the size and localisation of the adenoma. Possible alternatives are enucleation, partial resection of the pancreas, resection of the head of the pancreas and pancreatectomy. In resection of the head of the pancreas fresh implantation of the remainder of the pancreas and common bile duct with the jejunum by means of invaginating suture technique with no more than point-sized opening of the gut has proved advantageous. The dreaded complications of pancreatic fistula and peritonitis could thus be prevented.

Zusammenfassung. Voraussetzung für ein erfolgreiches operatives Vorgehen beim organischen Hyperinsulinismus ist die gezielte Diagnostik mit provozierter Hyperglykämie, Plasmainsulinbestimmung (IMI) und die selektive Arteriographie. Die Art der Operation richtet sich nach Größe und Lokalisation des Adenoms. Die Enucleation, die Pankreasteilresektion, die Pankreaskopfresektion und die Pankreatektomie stehen operativ zur Verfügung. Bei der Pankreaskopfresektion bewährte sich die Neueinpflanzung des Restpankreas und des Choledochus mit dem Jejunum mittels einer invaginierenden Nahttechnik und nur punktförmiger Darmeröffnung. Die so gefürchteten Komplikationen von Pankreasfistelungen und Peritonitis konnten damit vermieden werden. 